\title{
Malaysian high schoolers' reading literacy performance: Trends and patterns across states
}

\author{
Marcia Jane Ganasan ${ }^{1}$, Nordin Abd. Razak ${ }^{2}$, and Marlina Jamal ${ }^{3}$ \\ ${ }^{1}$ Independent Scholar, Universiti Sains Malaysia,11800 Minden, Pulau Pinang, Malaysia \\ ${ }^{2}$ School of Educational Studies, Universiti Sains Malaysia,11800 Minden, Pulau Pinang, Malaysia \\ ${ }^{3}$ School of Languages, Literacies \& Translation, Universiti Sains Malaysia,11800 Minden, Pulau Pinang, \\ Malaysia
}

\begin{abstract}
Reading literacy is often understood as a basic skill, and it is gaining recognition as the most functional means to educational attainment and individual development. It not only sets a benchmark but also reveals students' strengths and weaknesses through performance measurement. This paper attempts to investigate sixteen-year-olds' reading literacy proficiency using a performance band system in reporting their 'can's and 'cant's in reading. It drew insights from the Text-Task Respondent Theory of Functional Literacy (White, 2011) and the Revised Bloom's Taxonomy (Anderson \& Krathwohl, 2001), where pertinent concepts were drawn to address students' functional abilities. The study involved a total of 813 sixteen-year-old students representing the northern, southern, central, and east coast regions of Peninsular Malaysia (Penang, Perak, Perlis, Selangor, Kedah, Kelantan, Terengganu, and Johor). A survey research method was employed to capture cognitive competencies that denoted students' functional abilities when it came to reading literacy. The study measured the students' reading literacy attainment based on a proficiency scale spanning on five-band levels. The findings of the present study revealed that the majority of the students attained Band 3, where they demonstrated a moderate understanding of texts and were able to integrate some part of texts to infer meaning. The study provides valuable insights to policymakers, educationists, employers in making datadriven decisions to improve educational outcomes. It also attempts to shed some light on the current pedagogical trends and provide suggestive practices in reading.
\end{abstract}

Keywords: cognitive skills; functional literacy; literacy performance; reading literacy

\begin{tabular}{ccc} 
First Received: & Revised: & Accepted: \\
3 January 2020 & 31 March 2020 & 14 April 2020 \\
Final Proof Received: & & Published: \\
23 May 2020 & & 31 May 2020 \\
\hline
\end{tabular}

How to cite (in APA style):

Ganasan, M. J., Razak, N. A., \& Jamal, M. (2020). Malaysian high schoolers' reading literacy performance: Trends and patterns across states. Indonesian Journal of Applied Linguistics, 10(1), 161-172. https://doi.org/10.17509/ijal.v10i1.25031

\section{INTRODUCTION}

Reading is a required skill that is vital in every stage of an individual's development that turns crucial in the middle years of schooling for career and success in the adult life (Smith et al., 2000; Cunningham \& Stanovich, 1998). One cannot deny that reading for functional purposes is required for personal growth and effective participation in the current global and economic world (Post, 2016). The fundamentals of reading have to be built by employing different task demands to sharpen cognitive skills (White, 2011). However, the challenges of participating in a

\footnotetext{
* Corresponding Author

Email: g.marcjane@gmail.com
}

knowledge-based society require the ability to utilise information in practical ways and to understand and employ information from various sources of texts. Functional literacy has become one of the world's most prime currencies in the $21^{\text {st }}$ century requiring young adolescents to be up-skilled to utilise texts effectively (OECD, 2000). Within this tenet, functional literacy is described as the core skill necessary for developing human well-being (Nussbaum, 2006). A strong grasp in functional literacy may potentially allow students to secure on 
greater access to education and career opportunities (Tett \& Fye, 2010; Kern \& Friedman, 2008; Pretorious, 2000; Stenner, 1996). Functional literacy is seen as the ability to operate using the dimensions of cognitive processing skills to comprehend texts to participate effectively in academics, job market and the future.

The roles of reading have progressively taken on different definitions and shapes drawing on different focus with time. The first shift took place from the mode of oral reading to silent reading in the classroom. Formal reading comprehension has always been part of every reading activity in the classroom dating back to the $20^{\text {th }}$ century (Pearson $\&$ Hamm, 2005). A significant breakthrough in reading took place when silent reading was extended to include new constructs of testing without professional judgment. Moreover, the ever-growing amount of information necessitates that critical thinking becomes even more important with the era of industrial revolution 4.0 that is raking at an unpredictable rate and readers need to evaluate and synthesise information from texts. The approach towards reading changed decades ago, and it is highly predictive that a shift is bound to take place in times ahead. The effect is obvious when key stakeholders are coming to realise that the total sum of individuals' abilities is the most crucial form of capital (Coulombe et al., 2004). The crux of this matter points out that one cannot escape the skillsets that are needed in today when it comes to information processing. Therefore, performance in literacy is used as a yardstick mirror to place students in their respective literacy levels to gauge students' readiness in vital subjects such as reading, science and mathematics (Cardoso \& Guadalupe, 2011).

Reading literacy somehow poses different concerns in the millennium. Even though individuals can read and write, learners are unable to cope with the required readings in the $21^{\text {st }}$ century (Semry \& Mahendran, 2015; Che Musa et al., 2012; Harrison, 2010; Koo, 2001; Darling- Hammond (2010); Mullis et al., 1990) found that today's students' literacy achievement is unacceptably low to meet the country's needs and goals for personal and national aspirations. The findings of a study conducted by Marlia et al. (2016) showed that students lagged in the skills to integrate and interpret texts when it comes to higher-order skills. Li and Chun (2012) assessed the effects of memorising and elaboration strategies to understand the reading competencies of 15-year-olds based on the 2002 Hong Kong Program for International Student Assessment. The findings showed that students focused more on retention strategies rather than elaboration. The researchers suggested educators employ a direct instruction approach that focused on elaboration skills to successfully facilitating students' reading literacy performance. In Ghana, Stoffelsma (2018) examined the reading behaviours of tertiary ESL students using diaries with entries recorded at 6364 hours. The results showed that the students spent limited hours on processing their academic texts compared to the hours spent on their assignments. The findings showed that tertiary students who had low levels of reading proficiency not only had difficulty in comprehending texts but also in enjoying reading, pointing to a low reading preparedness. The net effect showed that although the students had the ability to read, they somehow fell on the continuum of uncritical readers when it came to processing and comprehending information from texts (Baki et al., 2016; Kadir et al., 2014). The impact of reading on education is to develop critical thinking skills that form the foundational bases for other learning subjects (Rutherford-Becker \& Vanderwood, 2009). These dynamics show that education practitioners should teach in a way that foster critical thinking to capture students' perceived areas of strengths and weaknesses to impact reading literacy.

Reading involves understanding and reflecting on written information for a variety of purposes as learners are required to retrieve information, form a broad general understanding and evaluate the content of the texts (PISA, 2009; OECD, 2003). In today's age, attaining a robust level of functional capability and thinking skills in managing information that learners encounter in their lives is vital. White (2011) states that every learner possesses a set of profile skills as various activities, and the assessment task requires different levels of processing skills. The core concepts of literacy performance are designed to document 'what might be' as the possibility of profiling young adults' preparedness and their ability to analyse, reason and communicate ideas throughout life (PISA, 2015). To be functionally successful, one needs to be flexible as well as adaptable to a changing world (Esposito et al., 2011). From the various attempts in defining functional literacy, the emphasis on reading is on the individual's ability to reflect and apply information in everyday interaction (PISA, 2009; UNESCO, 2006). In that stance, this study measures sixteen-year old's reading literacy to elicit their reading proficiencies and level of attainment across the states of Peninsular Malaysia.

\section{Reading literacy}

Reading is often understood simply by decoding or reading aloud, whereas reading literacy includes a wide range of cognitive competencies from necessary decoding of words, grammar, linguistics and textual structure and features. To fully understand a text, students must view reading as an active process rather than a passive activity. Byrnes (1998) states that skills, strategies and specific knowledge are determined by the purpose and type of text.

Reading comprehension takes place when the reader is aware of the appropriate skills and strategies of the kind of text and understands how to apply them to accomplish its purpose. Active reading involves an 
engaged mind, along with the working of critical thinking skills. It is the highest order of activity of the brain when it processes information simultaneously. Active reading also involves keeping up open communication while understanding the flow of information to create a systematic scheme of knowledge. This type of reading leads to true meaningful learning, where reading is a vital skill of study.

In today's information culture, students need to be familiar with strategies that allow them to read effectively with a reasonable amount of time spent on reading. They need to understand the semantic aspect of the written materials, identifying the main points of the text that requires choosing vital information. Cognitive paradigms attempt to explain the processes of the minds when engaging in complex mental activities (Tracey et al., 2010). Learners are required to understand complex texts and answer complicated questions that need interpretation and various diverging sources of knowledge to solve problems (Ortlieb et al., 2013). Therefore, learners cannot escape but face the reality of functional reading. Functional literacy is the ability to understand and use literate behaviours for individual development and functioning.

Functional literacy is defined as the ability to execute a multifaceted set of tasks to meet personal, social and workplace needs in the 'New Times' (OECD, 2002). It refers to knowledge and skills that are used to understand written items of information that involve a multiplicity of skills when it comes to processing information (Murray, 1997). The notion of functional literacy connects to all forms of learning affecting individuals in various ways. Researchers opine that basic skills such as interpretation, calculations, chart readings and problem-solving skills require decisions that are perfunctory skills in today's workforce (Comrie \& Murray, 2009).

\section{Text-Task respondent of functional literacy}

Text-Task Respondent (TTR) of functional literacy was introduced by White (2011) in view that students respond to task demands by capitalising on their cognitive processing skills. The integration of these skills is also known as pragmatic skills. The theory emphasises the use of function and application of printed and written materials to accommodate the definition of functional literacy. The framework consists of three components, namely text features, task demands, and respondent skill. The component of text features is made up of words, sentences and visual representations that affect or influence the task. Task demands refer to the cognitive and linguistic processes required for the completion of literacy task, while respondent skills are employed to perform the task. The requirements of the text correlate with learners' respondent skill to successfully operate to be functionally literate. These skills correspond to the demands and characteristics of text which influence the learners' cognitive processing skills. Situational context, background knowledge, and text features affect the reader's overall respondent skill.

Functional literacy captures the concepts of semantic and pragmatic skills. Semantic skills refer to one's linguistic ability to read and understand texts meaningfully with knowledge of phonology, lexicon, and syntax. The components of text search, inferential skills, and application skills that fall under pragmatic skills are used to combine new information to gain understanding. At this stage, various cognitive processes are operationalised to respond to the corresponding task demands. Application skill refers to the ability to use underlying knowledge and transfer the related association of knowledge to match the task. Constantly, students need to retrieve, interpret, analyse and evaluate information from texts to problem solve. This operation requires individuals to be functionally literate to be flexible and adaptable to manoeuvre information that is growing in texts. The coordination of these domains necessitates the streaming of students' literacy task performance. The theory suggests that functional literacy requires semantic and pragmatic skills that call on multiple skills when processing texts. In other words, the integrative nature of these skills plays important roles in accomplishing literacy task and attaining literacy performance.

\section{A revision of Bloom's Taxonomy}

The emergence of a knowledge society welcomes the ability to think in unimaginable and critical thereby needing individuals to be functionally literate in employing and demonstrating cognitive skills (Kivunja, 2015; Kadir et al., 2014; Murnane \& Snow, 2012; Rotherham \& Willingham, 2010). In recent years, thinking skills have been enlisted as one of the $21^{\text {st }}$-century skill set that is valuable. The value of living in an information society does not lie in having access to amass of information but lies in the ability to employ thinking skills on a variety of levels drawing knowledge from different fields. In that sense, critical thinking is defined as the "likelihood that one will approach problem framing or problemsolving by using reasoning consistent with internal motivation to engage problems and make decision by using thinking" (Giancarlo \& Facione, 2001, pp. 3031). Under the caveat of cognitive thinking, the cognitive taxonomy shows students' cognitive ability based on learning outcomes and instructional activities (Omar et al., 2015; Anderson \& Krathwohl, 2001). The taxonomy provides an inclusive approach that meets the skills of diverse learners and instructors.

Bloom's taxonomy is a tool to measure various constituents of critical thinking into a trainability of skills. Due to its versatility and unique educational features, Bloom's Taxonomy fits into various fields of education, sciences, engineering, mathematics, 
chemistry and so forth. Numerous studies have been integrated into Bloom's to enhance and evaluate learning outcomes (Fiegel, 2013, Thambyah, 2011). It makes the taxonomy a suitable tool for a transdisciplinary study that emphasises on thinking skills (Sharunova et al., 2018). The application of Bloom's taxonomy in education is strongly linked to the development of higher and lower-order thinking skills such as comprehending, analysing, evaluating and problem-solving skills. The original idea of Bloom's taxonomy was intended to provide clarity and accuracy to the educational objectives which were potentially challenging. The argument put forth by earlier researchers suggested that components of knowing and understanding are not only difficult to measure but also tedious to teach. The operational definition of critical thinking lacks a definitive shape that leads to abstract concepts due to its broad nature. The teaching of thinking skills falls into two broad categories referred to as the generalist and the nongeneralist. The former holds that thinking skills can be generalised and taught without requiring any particular context. The latter, pioneered by McPeck (1981) states that thinking occurs in a particular context as thinking without disposition, does not hold much value. Thinking skills are now the life-long skills as half of the information today is estimated to obsolete in the next five to ten years rendering what students once knew of little significance (Crow, 1989). In situations when students lack thinking abilities, they risk "having all the answers but not knowing what they mean" (Halpern, 1998, p. 450). The proliferation of information has sparked the importance of having the ability to think (Robinson, 2011). Thinking skills must also answer the obligation that calls for depth and clarity in the expression of thinking. However, the concocted disposition lacks the how's' of inculcating these matters in the minds of the students. IR 4.0 is predicted to affect all the domains of Bloom's model, and the cognitive model of the higher-order skills such as application, analysis, evaluation and creation will become way more valuable than the lower-order thinking skills (Kargar et al., 2013). To solve the many problems in our surroundings, it requires many kinds of thinking that is central to finding solutions. Thinking takes on a multifaceted view, especially in a diverse world that we live and pointing to the situations we encounter that different demand formulation of thought. The acquisition of thinking requires specific and vital skills in learning the subject thoroughly well. Since the process of thinking in itself is accounted for by making references to particular instances, the acquisition of thinking is vital in learning any subject successfully (DiYanni, 2017; Clinton, 2011).

Reading is a complex domain that comprises the ability to cope with texts that require readers to perform different operations such as to retrieve and locate information, integrate information to make inferences. As can be seen in Figure 1, this process requires a combination of elements as pointed out by White (2011) in the Text-Task Respondent Theory of Functional Literacy (TTR). The theory suggests that readers rely on semantic and linguistic competence to decode words which is a basic skill. However, measuring students ability to read is not enough since pragmatic competence demands readers to understand, analyse, evaluate, compute and execute tasks to solve problem apart from reading. In this regard, Bloom's Taxonomy attempts to explain the cognitive aspect that is part of the learner's repertoire. Since the process of thinking in itself is accounted for by making references to particular instances, the acquisition of thinking skills is vital in learning any subject successfully. Failure to acquire the related skills would negate and complicate the development of a society. In this approach, the coordination of task demand and respondent skill necessitate the order of literacy task performance.

\section{METHOD}

The study involved 813 students consisting of 373 male and 440 female students from the states of Penang, Kedah, Perak, Perlis, Selangor, Kelantan, Terengganu, and Johor (see Table 1). A (20\%) nonstratified equal probability sampling technique was used to select samples from the total cohort of Form Four students in the selected schools.

\section{Table 1}

Sample Population across the States

\begin{tabular}{lc}
\hline States & $\mathbf{2 0 \%} \begin{array}{c}\text { of students from the selected } \\
\text { schools }\end{array}$ \\
\hline Penang & 77 \\
Perlis & 76 \\
Kedah & 77 \\
Perak & 115 \\
Selangor & 115 \\
Kelantan & 115 \\
Terengganu & 115 \\
Johor & 123 \\
Total & $\mathbf{8 1 3}$ \\
\hline
\end{tabular}

\section{School selection}

A total of sixteen mainstream secondary schools from urban and rural schools participated in this study. Every state was represented by an urban and a rural school suggested by the State Education Departments. A purposive sampling technique was employed in the selection of schools. A sample size calculator was used to determine the sample population of the school with a confidence level of $95 \%$ and a margin rate of 5\%. A sample size of $20 \%$ was determined to select students from the cohort of Form Four students. A stratified sampling technique was employed to determine the number of students enrolled in the arts or science streams.

\section{Reading literacy test}

The reading test also aimed to measure learner's functional abilities in carrying out the tasks. The test 
development involved a series of stages. The initial stage involved appropriate material selection in choosing the stimulus. The items were calibrated to match the assessment framework of PISA 2012 (OECD, 2013). The items were arranged on a stimulus assessing knowledge and cognitive processing skills in each domain. During the development stage, experts with considerable teaching experiences provided feedback. The items were arranged to evaluate knowledge and cognitive processing skills to ensure that the item matches the suitability of reading domain before administering the actual study. The items were tailored to elicit cognitive skills by employing Anderson and Krathwohl's (2001) Revised Bloom's Taxonomy and White's (2011) Text-Task Respondent Theory. Figure 2 shows the procedures in developing the test of the study.

\section{Figure 1}

Coordination of Literacy Skills in Performing Literacy Skills (Adapted from White, 2011, p. 58)

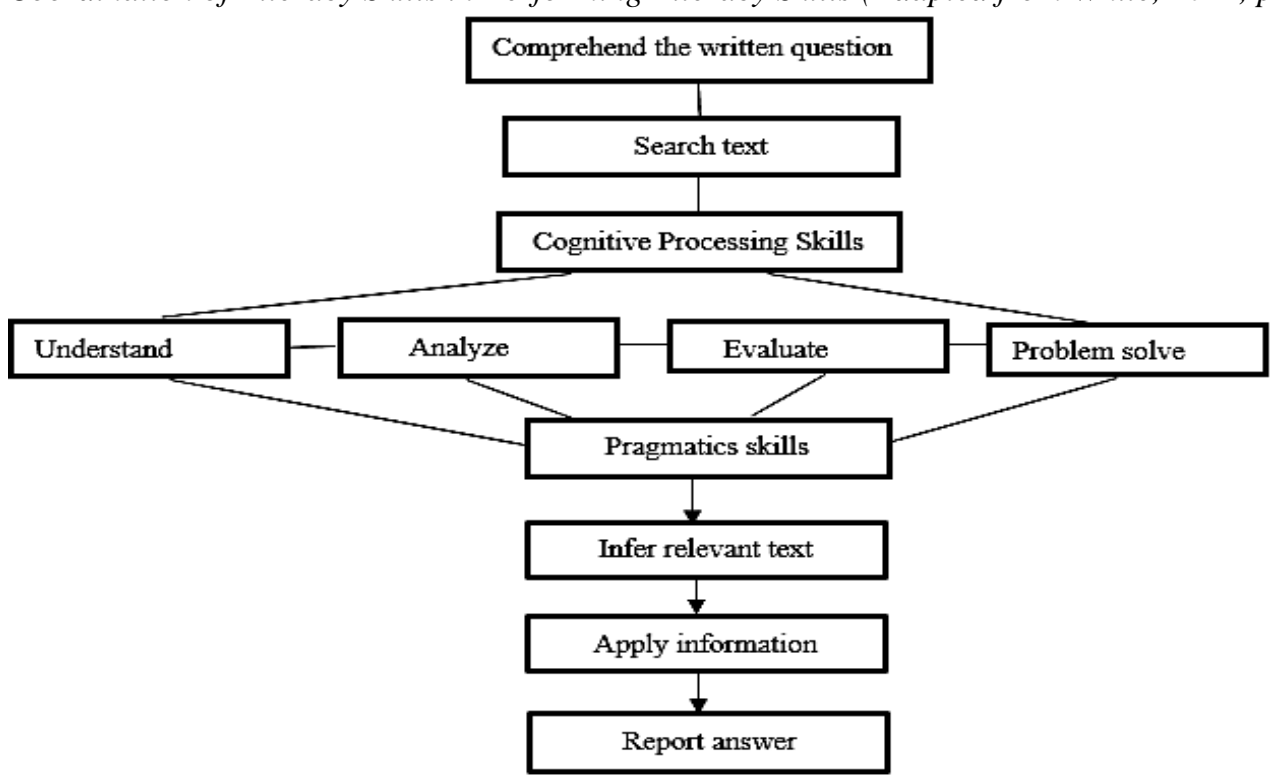

Figure 2

Procedures of Test Development

\begin{tabular}{|c|c|}
\hline Conceptualization & $\begin{array}{l}\text { - Identifying Domain Specification } \\
\text { - Defining the constructs }\end{array}$ \\
\hline \multirow[t]{2}{*}{ Development of Measures } & $\begin{array}{l}\text { - Generate items to represent the construct } \\
\text { - Generating item pools }\end{array}$ \\
\hline & Step 2 \\
\hline \multirow[t]{2}{*}{ Framework Specification } & - Matching items to the framework \\
\hline & Step 3 \\
\hline \multirow[t]{2}{*}{ Scale Refinement } & $\begin{array}{l}\text { - } \quad \text { Refining item descriptors } \\
\text { - Refinement and purification of scales }\end{array}$ \\
\hline & Step 4 \\
\hline \multirow[t]{2}{*}{ Validation } & $\begin{array}{l}\text { - } \quad \text { Refining the instrument } \\
\text { - Validating the content with experts }\end{array}$ \\
\hline & Step 5 \\
\hline \multirow[t]{2}{*}{ Testing } & $\begin{array}{ll}\text { - } & \text { Pilot Test } \\
\text { - } & \text { Modification and revision after piloting }\end{array}$ \\
\hline & Step 6 \\
\hline
\end{tabular}


The revised Bloom's Taxonomy was employed to determine knowledge and cognitive processing skills (see Figure 3). Knowledge domains were carefully constructed to measure cognitive items that fall within the reading text. Since students were required to perform tasks that aligned with functionality, the culmination of Text Task Respondent Theory and Revised Bloom's Taxonomy anchored the performing tasks of cognition.

Figure 3

Cognitive Processing Skills

\begin{tabular}{|c|c|c|c|c|c|}
\hline \multicolumn{6}{|c|}{ Cognitive Processing Skills } \\
\hline \multicolumn{2}{|c|}{ Remember } & Understand & Apply & Analyse & Evaluate \\
\hline 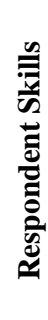 & $\begin{array}{l}\text { recognise } \\
\text { - identify } \\
\text { recall } \\
\text { - retrieve }\end{array}$ & $\begin{array}{l}\text { interpret } \\
\text { - clarify } \\
\text { - categorise } \\
\text { summarise } \\
\text { - generalise } \\
\text { infer } \\
\text { - conclude } \\
\text { - extrapolating } \\
\text { - predicting }\end{array}$ & $\begin{array}{l}\text { execute } \\
\text { • implement }\end{array}$ & $\begin{array}{l}\text { differentiate } \\
\text { - discriminate } \\
\text { - distinguish } \\
\text { - select } \\
\text { organise } \\
\text { - find coherence }\end{array}$ & $\begin{array}{l}\text { check } \\
\text { - coordinate } \\
\text { - detect } \\
\text { - monitor } \\
\text { critique } \\
\text { - judge }\end{array}$ \\
\hline
\end{tabular}

\section{Reliability of reading literacy test}

To determine the reliability of the reading test, a splithalf method was used to assess the internal consistency of the test with a group of 50 students for pilot testing. The test that comprised of 30 questions was divided into two parts of even and odd-numbered items. The scores from both parts were correlated; the result of the Cronbach Alpha showed an acceptable value of 0.82 .

\section{Literacy band performance}

The band performance comprises of Band 1, Band 2, Band 3, Band 4 and Band 5 to determine students' literacy attainment based on their scores (minimum score is 0 , and the maximum score is 100). The classification of performance bands disseminates vital information regarding learner's abilities which describe levels of performance typically on what students know and can do in their reading literacy. For the purpose of this study, the results were analysed using descriptive statistics to provide an overview of the reading trends of sixteen-year-olds' across the states. The description for each band is divided into five levels, as shown in Table 2.

Table 2

Literacy Band Performance Indicators

\begin{tabular}{|c|c|c|c|}
\hline Bands & & $\begin{array}{l}\text { Reading } \\
\text { Scores } \\
(\%)\end{array}$ & Reading Indicators \\
\hline Advanced & 5 & $81-100$ & $\begin{array}{l}\text { At this level, students are able to recognise implicit and explicit meanings } \\
\text { from texts and show strong connections by inferring meanings from the } \\
\text { texts demonstrating sound understanding coherently. }\end{array}$ \\
\hline Proficient & 4 & $61-80$ & $\begin{array}{l}\text { At this level, students are able to integrate multiple perspectives to identify } \\
\text { the main idea of the texts and link information within the texts } \\
\text { demonstrating clear understanding. }\end{array}$ \\
\hline Basic & 3 & $41-60$ & $\begin{array}{l}\text { At this level, students are able to use modest information to recognise and } \\
\text { somewhat draw connections between pieces of information to identify the } \\
\text { main idea of the text demonstrating basic understanding. }\end{array}$ \\
\hline Prerequisite & 2 & $21-40$ & $\begin{array}{l}\text { At this level, students are able to locate less clearly stated information } \\
\text { from the texts and draw connections that are incoherent to the texts } \\
\text { demonstrating a low understanding. }\end{array}$ \\
\hline $\begin{array}{l}\text { Far below } \\
\text { basic }\end{array}$ & 1 & $20-0$ & $\begin{array}{l}\text { At this level, students are able to only locate explicit information from the } \\
\text { texts and make limited connections of the texts and real-life situations } \\
\text { demonstrating a very limited understanding. }\end{array}$ \\
\hline
\end{tabular}

\section{FINDINGS AND DISCUSSION}

Table 3 and Figure 4 show the students' performance in reading literacy across the states in Peninsular Malaysia. The findings of the study showed that $55 \%$ of the students from the overall sample population achieved Band 3, followed by $26 \%$ of students fell into Band 2, and $14 \%$ of students attained Band 4 (see Table 4.1). Also, $81 \%$ of the students who comprised 
Band 3 and Band 2 scorers possessed basic and prerequisites levels of reading literacy. The states that observed a majority of Band 3 scores were noticeably from Perlis $(69.7 \%)$, Kelantan $(65.2 \%)$ and Terengganu (59.1\%). Band 4 scorers dipped in numbers and comparatively have the most scorers from Penang (30\%), Kelantan $(20 \%)$ and Perak (16\%) respectively. Overall, we can observe a downward trend in the overall projection of the reading performance of the sample population across the states. The percentage for Band 5 scorers is significantly lower compared to Band 1-4 scorers thereby charting the states of Johor (3\%), Kedah $(2.6 \%)$, Penang (1\%), and Kelantan $(0.9 \%)$ as having the most scorers at this level. Although, almost all the states trended towards Bands 3, 2, and 4, only scorers from Penang peaked at Band 3 and ascended to 4 before declining to Band 2. Also, only $1 \%$ of the students from the total sample population attained Band 5 in reading literacy.

Table 2

Distribution of Band Performance in Reading Literacy in Peninsular in Malaysia

\begin{tabular}{llllll}
\hline States & $\begin{array}{l}\text { Band 1 } \\
(\boldsymbol{\%})\end{array}$ & $\begin{array}{l}\text { Band 2 } \\
(\boldsymbol{\%})\end{array}$ & $\begin{array}{l}\text { Band 3 } \\
(\boldsymbol{\%})\end{array}$ & $\begin{array}{l}\text { Band 4 } \\
(\boldsymbol{\%})\end{array}$ & $\begin{array}{l}\text { Band 5 } \\
(\boldsymbol{\%})\end{array}$ \\
\hline Perak & 8.7 & 21.7 & 53.9 & $15.7(3)$ & \\
Selangor & 3.5 & $42.6(1)$ & 48.7 & 5.2 & 0.9 \\
Kelantan & & 13.9 & $65.2(2)$ & $20(2)$ & 3.3 \\
Johor & 4.1 & 20.3 & 52.8 & 19.5 & 2.6 \\
Kedah & 7.8 & $28.6(3)$ & 45.5 & 15.6 & 1.3 \\
Penang & 1.3 & 23.4 & 44.2 & $29.9(1)$ & \\
Perlis & 1.3 & 26.3 & $69.7(1)$ & 2.6 & \\
Terengganu & 1.7 & $33.9(2)$ & $59.1(3)$ & 5.2 & \\
*Bank cells indicate no data available & & *Rankings are in parenthesis ( )
\end{tabular}

Figure 4

Performance Trends and Patterns Reading Literacy in Across States

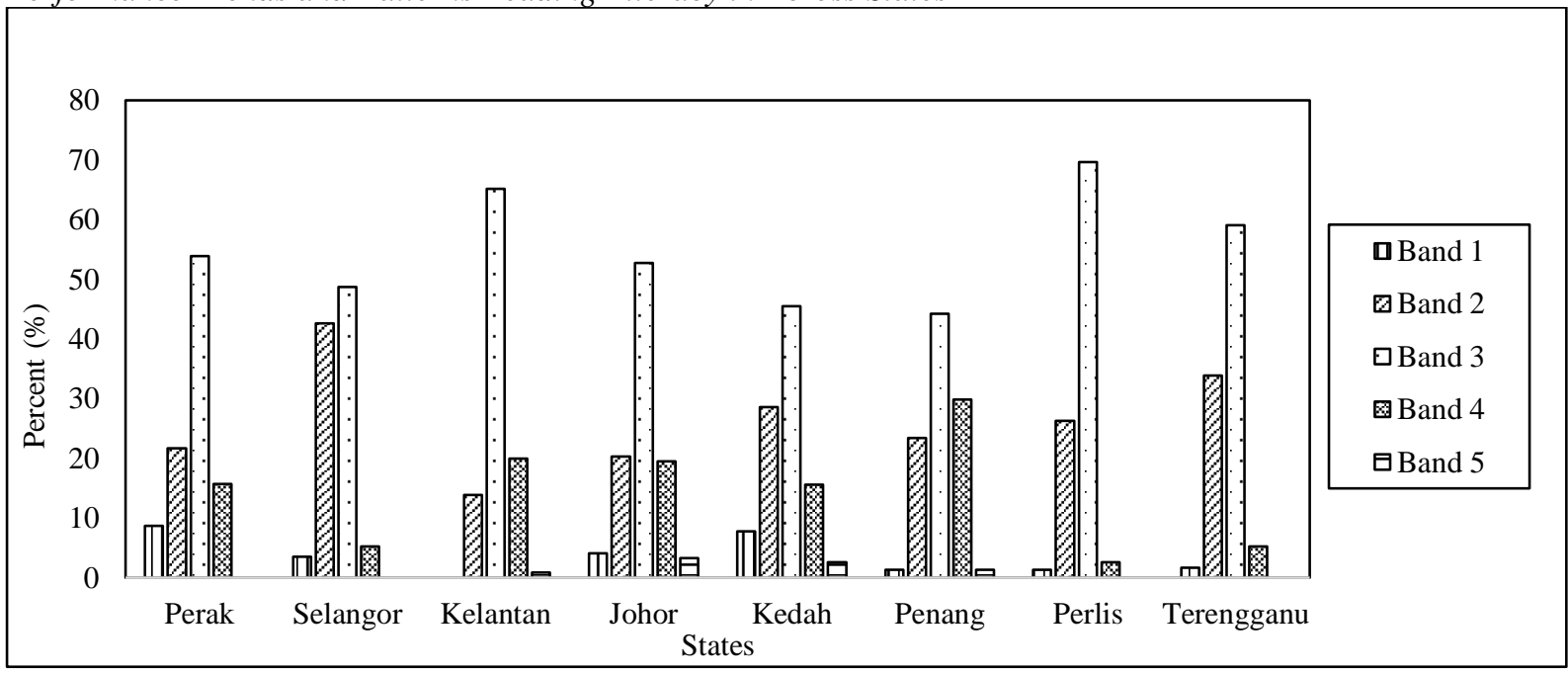

The study aims to provide an overview of reading literacy trends across the states in Malaysia. The overview trend of reading performance shows that sixteen-year-old students generally attained Band 3 across the states. Within each state, there were students who performed exceptionally well and severely poor across the literacy continuum. Every state had students failing to attain Band 1, and others showing advanced reading skills at Band 5. The trend shows of such occurrences between the two bands are fewer than $1 \%$ from the sample population across the states. The findings on the students' performance can be understood in terms of students who attained the highest band and students who failed to progress at the baseline level of reading literacy thereby falling behind at the prerequisite and far below basic levels.
The data showed that the majority of the students attained a basic literacy of Band 3 (41-60\%) across the states. At this level, they could identify and recognise simple information to identify main ideas from the texts. Students were somewhat able to exhibit a general understanding of the text but could not draw connections with the texts. Consequently, they had not fully acquired the skills to evaluate information from texts successfully. Band 3 scorers were found to be proficient at retrieving information and comprehending texts of low-level inferences. However, these students were not able to progress to the next level for their inability to draw connections and provide sound explanations.

It is a matter that calls for deep concern addressing students who fell below the baseline level 
of Band 3 in their reading literacy performance. Also, Band 2 scorers were only able to locate less precise information and draw explicit information from texts. Students who dipped at the lowest-performing level of Band 1 showed very limited understanding at the semantic level falling far below the basic level of the band scale. These students had minimal input in comprehending information from texts and could only make a simple connection in single information. The findings showed that at least one out of three students was unable to perform basic reading tasks (Bands 1 and 2). In order to become a functional reader, students are required to meet multiple skills in locating and understanding texts to functionally participate in society effectively or they potentially risk facing post-secondary education challenges and limited job opportunities.

At higher literacy attainment, only $15 \%$ of the students who attained a higher proficiency level of Band 4 and Band 5 were able to comprehend texts but could also recognise implicit information to form a logical argument. The students at a higher literacy spectrum possessed these characteristics as they were able to organise and apply information in drawing appropriate answers that are less directly obtained from texts. Band 4 scorers were able to integrate information from texts but lacked the ability in forming arguments based on evidence. Although the percentage of Band 1 scorers was relatively low, the students who attained a higher literacy continuum of Bands 2 and 3 had the potential to progress to a higher literacy equilibrium. The theory of TTR conceptualises semantic and pragmatic domains as interdependent skills in bridging cognitive skills. The processes of thinking skills are the key faculty that allow students to be functionally literate in solving task demands successfully. It is important to keep up with the demands of a changing global landscape that require education to be delivered relevant to the current needs of employment (Aziz et al., 2018). The process of thinking not only allows students to utilise their various thinking abilities such as to understand, analyse and evaluate information but also gives learners the edge to become functionally competent. Therefore, students' respondent skills become part of their functional skills. The ability to succeed in critical life pursuits is dependent on one's functional literacy to solve problems when equipped with the necessary skills.

Bloom's Taxonomy provides a concise framework that shows the individual's ability to use a set of cognitive skills. Many outcomes that are part of this domain include the ability to understand, analyse, evaluate and solve problems are necessary skills for both academic and work success. Functional literacy reflects the typical use and standard requirements in attaining basic key skills for career and life. It has become part of readers' lives to seek information from various sources ranging from identifying departure time for the bus in a brochure to establishing facts to make or refute a claim. To enhance one's critical thinking skills, students should participate in activities that employ information and communication skills as part of their everyday learning. The core elements of these activities should encompass various levels of critical thinking skills instead of conventional literacy that focuses on surface information processing. Exposure to functional skills is fundamental in developing students' cognitive skills (White, 2011). The implication of this study suggests that in order to create a critical thinking community, both the internal and external systems need to reverberate students' cognitive and functional skills. Although students have access to conventional learning, students generally need abundant opportunities to practice and enhance their thinking skills.

A major educational challenge lies in fostering cognitive proficiency as the basic goal to improve the quality of thinking. For some, thinking is a natural process that does not require formal teaching (Sternberg \& Williams, 2002). Researchers like Duron et al. (2006) counterfeit the argument stating that formal teaching is still much required for excellence among students. The Malaysian Ministry of Education (2013) has sanctioned the importance of higher-order thinking skills as part of its testing and evaluation policy. There is a need to infuse authentic learning that mirrors real-life situations in measuring literacy performance (Semry \& Mahendran, 2015; Kadir et al., 2014; Che Musa et al., 2012; Harrison, 2010). Although the onus also falls onto the hands of educators in moulding students into becoming leaders, the researchers opine that teachers are also somewhat constrained by students' abilities, densed syllabus content and other possible reasons that halt their teaching in promoting HOTS.

Classroom reading practices facilitated towards higher-order thinking is effective when conducted with practical activities at a scaffolding level. Classroom instructions that focus on various questioning techniques, interpreting of mental imagery and symbols, comparing and contrasting information, and opinions and experiences help in broadening abstract thinking skills and launching students to a whole range of environments. Students need to learn to manipulate ideas in the texts they read using thinking skills. Instructions that focused on teacher-centred learning and lower-order thinking skills inhibit the expansion of higher-order thinking skills (Chun \& Abdullah, 2019). Other modes of teaching pedagogies including problem-based learning, inquiry teaching, brainstorming, constructivist learning and thinking map are some of the practices employed by educators of ESL in Malaysia (Hassan et al., 2018; Jerome et al., 2017; Kitot et al., 2010). The definition of best practices may differ from one context to another. Best practices in a particular setting may not deem appropriate or suitable in another classroom practice. Therefore, a 
teacher's discretion is highly required in reflecting classroom needs such as teaching pacing, access to quality materials, classroom organisation and other possible factors to calibrate and maximise students' potentials. The techniques mentioned thus far are research worthy that demonstrated its usefulness and applicability in reading. These strategies are used to indicate a positive relationship with reading that calls for policy and practical implications in school and at home (OECD, 2002).

In order to keep up with the rapid changes of knowledge, a high-level literacy capacity is required (UNESCO, 2006; Özenç \& Dogan, 2014). Measurement is an important aspect as we can't change what we don't measure for betterment and development of educational outcomes. A welldesigned intervention program could be provided to treat underperforming students either with individual tutoring or focused group coaching. The coaching will usually vary based on how the instruction is provided and how the content is administered and if professional development coaching is needed to provide instruction (Hiebert \& Taylor, 2000). A more challenging aspect would be in stimulating reading interests in students and meeting the needs and of those who are at the risk of literacy performance of those who have dropped below the basic literacy continuum.

A guided instruction would enable students to work on their experiential and reflective intelligence tapping on cognitive skills which are valuable in facilitating students higher-order thinking skills (Maher \& Hughner, 2005; Bridges, 1999; Graeff, 1997). Learning that encourages in-depth exploration, thinking out loud activities, illustrating concepts and relationships of a subject-specific domain are essential in activating thinking skills. To improve the under-represented and at-risk student population, Woolfolk (1998) suggests a need to consciously employ abstract thinking and procedures in the current education (Zohar et al., 2001).

The intention behind the efforts of benchmarking is to generate evidence on students' skill distribution and their achievement levels. In that case, mapping students' reading literacy serves as a 'check-up' to identify and minimise the effects of academic deterioration among adolescents. Students' literacy capabilities are perceived as a set of skills valued by key stakeholders and decision-makers. The screening stage is a crucial phase to identify atrisk students to render assistance and ensure that they perform at the expected benchmark level. Today's global economy requires a skill set that incorporates the ability to think at levels that far surpasses basic reading. Also, it is vital to acclimate students with the knowledge and cognitive skills to tackle demanding texts to nurture and prepare students in becoming functional readers.

\section{CONCLUSION}

The study provides an overview of students' literacy levels in reading performance in Malaysia. Skillbased reporting offers an overview of students' literacy skills concerning knowledge and cognitive processing skills in reading literacy. There is a need to train students to become competent readers who can adapt, reflect and evaluate texts critically. These are the essential markers of a competent reader in the 21 st century. However, to attain an effective result, none of the above could be easily achieved without careful monitoring from educators, researchers, and key stakeholders. The takeaway from this study shows that students need to synthesise information and evaluate arguments from multiple perspectives that align with deep comprehension, which involve processing skills. The implication of the findings points out that students require a strong foundation in processing cognitive tasks when it comes to specific skills such as the ability to analyse and evaluate. In a classroom setting, learning and drilling should intensely focus on exposing students to learn activities that primarily emphasised on cultivating critical thinking skills in systematic and developmental ways. In short, critical thinking skills is a required skill in order to survive in a global environment. It also works like a compass that promotes students' employability requirement in the workplace and helps in building a culture of innovation.

\section{REFERENCES}

Anderson, L. W., \& Krathwohl, D. R. (2001). A taxonomy for learning, teaching, and assessing: a revision of Bloom's taxonomy of educational objectives. Longman.

Aziz, A. H. A. A., Rashid, R. A., \& Zainudin, W. Z. W. (2018). The enactment of the Malaysian Common European Framework of Reference (CEFR): National master trainer's reflection. Indonesian Journal of Applied Linguistics, 8(2), 409-417. https://doi.org/10.17509/ijal.v8i2.13307

Baki, N. U., Rafik-Galea, S., \& Nimehchisalem, V. (2016). Malaysian rural ESL students critical thinking literacy level: A case study. International Journal of Education and Literacy Studies, 4(4), 71-80. https://doi.org/10.7575/aiac.ijels.v.4n.4p.71

Bridges, E. (1999). Experiential learning and customer needs in the undergraduate marketing research course. Journal of Marketing Education, 21(1), 51-59. https://doi.org/10.1177/0273475399211007

Byrnes, H. (1998). Reading in the beginning and intermediate college foreign language class. Center for International Education International Research and Studies Program, U.S. Department of Education. Retreived from 
ERIC database.

https://files.eric.ed.gov/fulltext/ED433724.pdf

Cardoso, M., \& Guadalupe, C. (2011). Measuring the continuum of literacy skills among adults: Educational testing and the LAMP experience. International Review Education, 57, 199-217. https://doi.org/10.1007/s11159-011-9203-2

Che Musa, N., Lie, K. Y., \& Azman, H. (2012). Exploring English language learning and teaching in Malaysia. GEMA Online Journal of Language Studies, 12(1), 35-51. http://ejournal.ukm.my/gema/article/view/20

Chun, T. C., \& Abdullah, M. B. (2019). The teaching of higher order thinking skills (hots) in Malaysian schools: policy and practices. MOJEM:Malaysian Online Journal of Educational Management, 7(3), 1-18. Retrieved from https://mojem.um.edu.my/article/view/18 591

Clinton, G. (2011). Educating for critical thinking: thought-encouraging questions in a community of inquiry. Higher Education Research \& Development, 30(3), 357-370. https://doi.org/10.1080/07294360.2010.499144

Crow, L. W. (1989). The why, what, how and who of critical thinking and other higher order thinking skills. In L.W. Crow (Ed.), Enhancing critical thinking in the sciences (2nd ed.) (pp. 9-16). Baylor College of Medicine.

Comrie, M., \& Murray, N. (2009). Life-Skills \& literacy: employers' perspectives on staff learning needs. The International Journal of Learning, 16(9), 387-400. https://doi.org/10.18848/14479494/cgp/v16i09/46550

Coulombe, S., Marchand, S., \& Tremblay, J. F. (2004). Literacy scores, human capital and growth across fourteen OECD countries. Statistics Canada.

Cunningham, A.E., \& Stanovich, K.E. (1998). Early reading acquisition and its relation to reading experience and ability 10 years later. Developmental Psychology, 33(6), 934945. https://doi.org/10.1037/00121649.33.6.934

Darling-Hammond, L. (2010). The flat world and education: How America's commitment to equity will determine our future. Teachers College Press.

DiYanni, R. (2017). Reading responsively, reading responsibly: An approach to critical reading. Critical Reading across the Curriculum: Humanities, 1, 1-23. https://doi.org/10.1002/9781119154907.ch1

Duron, R., Limbach, B., \& Waugh, W. (2006). Critical thinking framework for any discipline. Journal of Teaching and Learning in Higher Education, 17(2), 160-166.
http://isetl.org/ijtlhe/pdf/IJTLHE17(2).pdf\#pag $\mathrm{e}=89$

Esposito, L., Kebede, B. \& Maddox, B. (2011).

Literacy practices and schooling: A case study from Mozambique. World Development, 39(10), 1796-1807. https://doi.org/10.1016/j.worlddev.2011.04.011

Fiegel, G. L. (2013). Incorporating learning outcomes into an introductory geotechnical engineering course. European Journal of Engineering Education, 38(3), 238-253. https://doi.org/10.1080/03043797.2013.794200

Giancarlo, C. A., \& Facione, P. A. (2001). A look across four years at the disposition toward critical thinking among undergraduate students. The Journal of General Education, 50(1), 29-55. https:// doi.org/10.1353/jge.2001.0004

Graeff, T. R. (1997). Bringing reflective learning to the marketing research course: A cooperative learning project using intergroup critique. Journal of Marketing Education, 19(1), 53-64. https://doi.org/10.1177/027347539701900106

Halpern, D.F. (1998). Teaching critical thinking for transfer across domains dispositions, skills, structure training and metacognitive monitoring. American Psychologist, 53(4), 449-455. https://doi.org/10.1037/0003066x.53.4.449

Harrison, C. (2010). Why do policymakers find the 'simple view of reading' so attractive, and why do I find it so morally repugnant. In K. Hall, U. Goswami, C. Harrison, S. Ellis, J. Soler (eds.), Interdisciplinary perspectives on learning to read: Cognition, culture and pedagogy (pp. 207-218). Routdledge

Hassan, Z., Muthusamy, J., Tahir, L., Talib, R., Yusof, S. M., \& Atan, N.A (2018). The 21st century learning in Malaysian primary school: Exploring teachers' understanding and implementation of HOTS. Proceedings of the 1 st International Conference on Creativity, Innovation and Technology in Education (ICCITE). https://doi.org/10.2991/iccite18.2018 .69

Hiebert, E. H., \& Taylor, B. M. (2000). Beginning reading instruction: Research on early interventions. In M. L.Kamil, P.B. Mosenthal, P. D. Pearson, R. Barr (Eds.), Handbook of reading research, (Vol. III, pp. 455-482). Lawrence Erlbaum Associates.

Jerome, C., Lee, J. A., \& Ting, S. (2017). What students really need: Instructional strategies that enhance higher order thinking skills (HOTS) among UNIMAS undergraduates. International Journal of Business and Society, 18(4), 661-668. http://www.ijbs.unimas.my/images/repository/ pdf/Vol18-s4-paper2.pdf 
Kadir, N. A., Subki, R. N., Jamal, F. H. A., \& Ismail, J. (2014). The importance of teaching critical reading skills in a Malaysian reading classroom. Paper presented at the 2014 West East Institute International Academic Conference, Bali, Indonesia.

Kargar, F.R., Ajilchi, B., Goreyshi, M. K., \& Noohi, S. (2013). Effect of creative and critical thinking skills teaching on identity styles and general health in adolescents. Procedia-Social and Behavioral Sciences, 84(9), 464-469. https://doi.org/10.1016/j.sbspro.2013.06.585

Kern, M. L., \& Friedman, H. S. (2008). Early educational milestones as predictors of lifelong academic achievement, midlife adjustment, and longevity. Journal Applied Development Psychology, 30(4),419-430. https://doi.org/10.1016/j.appdev.2008.12.025

Kitot, A. K. A., Ahmad, A. R., \& Seman, A. A. (2010). The effectiveness of inquiry teaching in enhancing students' critical thinking. Procedia Social and Behavioral Sciences, 7(C), 264-273. https://doi.org/10.1016/j.sbspro.2010.10.037

Kivunja, C. (2015). Teaching students to learn and to work well with 21 st century skills: Unpacking the career and life skills domain of the new learning paradigm. International Journal of Higher Education, 4(1), 1-11. https://doi.org/10.5430/ijhe.v4n1p1

Koo, Y. L. (2001). Exploring the view of reading as social practice. In M. Maros and Q. C. Kin (eds.). Writings in applied lingistics in the Malaysian Context. Bangi: Universiti Kebangsaan Malaysia, 53-4.

Li, J., \& Chun, C. K. (2012). Effects of learning strategies on student reading literacy performance. The Reading Matrix, 12(1), 3038.

http://www.readingmatrix.com/articles/april_2 012/li_chun.pdf

Maher, J. K., \& Hughner, R. (2005). Experiential marketing projects: Student perceptions of live case and simulation methods. Journal for Advancement of Marketing Education, 7, 1-10. http://www.mmaglobal.org/publications/JAME /JAME-Issues/JAME-2005-Vol07Issue1/JAME-2005-Vol07-Issue1-MaherHughner-pp1-10.pdf

Malaysian Ministry of Education. (2013). Malaysia Education Blueprint. 2013-2025. MOE.

Marlia P., Zuhana M. Z., \& Ihsan I., (2016). Reading performance of Malaysian students across gender in PISA 2012. $3 L$ : Language, Linguistics, Literature ${ }^{\circledR}$ The Southeast Asian Journal of English Language Studies, 22(2), 109-121. https://doi.org/10.17576/31-2016-2202-08

McPeck, J. E. (1981). Critical thinking and education. Martin Robertson.
Mullis, I. V. S., Owen, E. H., \& Phillips, G. W. (1990). America's challenge: Accelerating academic achievement. Educational Testing Service.

Murnane, R. S. I., \& Snow, C. (2012). Literacy challenges for the Twenty-First Century: Introducing the Issue. The Future of Children, 22(2), 3-15. https://doi.org/10.1353/foc.2012.0013

Murray, T. S. (1997). Proxy measurement of adult basic skills: Lessons from Canada. In I. K. A Tuijnman \& D.A Wagner (Ed.), Adult basic skills: Innovations in measurement and policy analysis. Hampton Press.

Nussbaum, M. C. (2006). Education \& democratic citizenship: Capabilities and quality education. Journal of Human Development, 7(3), 385395. https://doi.org/10.1080/14649880600815974

OECD. (2000). Literacy in the information age: Final report of the international adult literacy survey. OECD.

OECD. (2002). Reading for change: Performance and engagement across countries: Results from PISA 2000. OECD.

OECD. (2003). The PISA 2003 assessment framework: Mathematics, reading, science and problem solving knowledge and skills. OECD.

OECD. (2013). PISA 2012 results in focus: What 15-year-olds know and what they can do with what they know. OECD

Omar, N., Haris, S. S., Hassan, R., Arshad, H., Rahmat, M., Zainal, N. F. A., \& Zulkifli, R. (2012). Automated analysis of exam questions according to Bloom's Taxonomy. ProcediaSocial and Behavioral Sciences, 59, 297-303. https://doi.org/10.1016/j.sbspro.2012.09.278

Ortlieb, E., Verlaan, W., \& Cheek, E. H. (2013). Fostering proactive reading instruction within the content areas. In E. Ortlieb \& E.H. Cheek (Ed.), School-based interventions for struggling readers, $K-8$ (Literacy Research, Practice and Evaluation, 3, 21-40. Emerald Group Publishing.

Özenç, E. G., \& Dogan, M. C. (2014). The development of the functional literacy experience scale based upon ecological theory (FLESBUET) and validity-reliability study. Educational Sciences: Theory and Practice, 14(6), 2249-2258.

Pearson, P. D., \& Hamm, D. N. (2005). The assessment of reading comprehension: A review of practices - past, present, and future. In S. G. Paris \& S. A. Stahl (Eds.), Children's reading comprehension and assessment (pp. 13-69). Erlbaum.

PISA. (2009). Measuring student knowledge and skills: A new framework for assessment. France: OECD Publications Service. 
PISA. (2015). Assessment and analytical framework science, reading, mathematics, financial literacy and collaborative problem solving. France: OECD Publications Service.

Post, D. (2016). Adult literacy benenfits? New opportunities for research into sustainable development. International Review of Education/Internationale Zeitschrift Fur Erziehungswissenschaft, 62(6), 751-770. https://doi.org/10.1007/s11159-016-9602-5

Pretorius, E. (2000). What they can't read will hurt them: reading and academic achievement. Innovation, 20, 33-41.

Robinson, S. R. (2011). Teaching logic and teaching critical thinking: Revisiting McPeck, Higher Education Research \& Development, 30(3), 275-287. https://doi.org/10.1080/07294360.2010.500656

Rotherham, A. J., \& Willingham, D. T. (2010). "21st-Century" skills not new, but a worthy challenge. American Educator, 34(1), 17-20. https://www.aft.org/sites/default/files/periodica ls/RotherhamWillingham.pdf

Rutherford-Becker, K. J., \& Vanderwoord, M. L. (2009). Evaluation of the relationship between literacy and mathematics skills as assessed by curriculum-based Measures. The California School Psychologist, 14(1), 23-34. https://doi.org/10.1007/BF03340948

Semry, A. S., \& Mahendran, M. (2015). Reading strategies among ESL Malaysian secondary school students. International Journal of Evaluation and Research in Education, 4(2), 54-61. https://doi.org/10.11591/ijere.v4i2.4492

Sharunova, A., Butt, M., \& Qureshi, A. J. (2018). Transdisciplinary design education for engineering undergraduates: Mapping of Bloom's taxonomy cognitive domain across design stages. Procedia CIRP, 70, 313-318. https://doi.org/10.1016/j.procir.2018.02.042

Smith, M. C., Mikulecky, L., Kibby, M., Dreher, M., \& Dole, J. (2000). What will be the demands of literacy in the workplace in the next millennium? Reading Research
Quarterly, 35(3), 378-383. https://doi.org/10.1598/rrq.35.3.3

Stenner, A. J. (1996). Measuring Reading Comprehension with the Lexile. Paper presented at the $4^{\text {th }}$ North American Conference on Adolescent/Adult Literacy, Washington DC.

Sternberg, R. J., \& Williams, W. M. (2002). Educational psychology. Allyn and Bacon.

Stoffelsma, L. (2018). Short-term gains, long-term losses? A diary study on literacy praciteces in Ghana. Journal of Research in Reading, 100(12), 1-19. https://doi.org/10.1111/14679817.12136

Tett, L., \& Fye, I. (2010). Community education, learning and development. Dunedin Academic.

Thambyah, A. (2011). On the design of learning outcomes for the undergraduate engineer's final year project. European Journal of Engineering Education, 36(1), 35-46. https://doi.org/10.1080/03043797.2010.528559

Tracey, D., Storer, A., \& Kazerounian, S. (2010). Cognitive processing perspectives on the new literacies. In E. A. Baker (Eds.), The new literacies: Multiple perspectives on research and practice (pp. 106-130). The Guilford Press.

UNESCO. (2006). Literacy for life. Paris: United Nations Educational, Scientific and Cultural Organization. Retrieved from http://www.uis.unesco.org/Library/Documents/ gmr06- en.pdf.

White, S. (2011). Understanding adult functional literacy: Connecting text features, task demands, and respondent skills. Routledge.

Woolfolk, A. E. (1998). Educational psychology. Allyn \& Bacon.

Zohar, A., Degani, A., \& Vaaknin, E. (2001). Teachers' beliefs about low-achieving students and higher order thinking. Teaching and Teacher Education, 17(4), 469-485. https://doi.org/10.1016/S0742051X(01)00007-5 